\title{
SAN AGUSTÍN Y LA ESTÉTICA DEL ROMANTICISMO ALEMÁN
}

\author{
MILAGROS GARCÍA VÁZQUEZ \\ Universidad Pontificia Comillas
}

\begin{abstract}
RESUMEN: El presente artículo plantea posibles conexiones entre el misticismo agustiniano y el pensamiento estético de San Agustín, con los principales fundamentos del Romanticismo alemán representado por tres autores, Wilhelm Heinrich Wackenroder y su texto Confesiones de un monje enamorado del arte, Caspar David Friedrich y su pintura Monje frente al mar, y Novalis y su obra lírica, narrativa y ensayística. De este modo, se busca dejar abierta otra posible vía de acercamiento al movimiento romántico y de conocimiento de sus ideales que pueda completar las perspectivas desde las cuales se han abordado hasta ahora las vidas y obras de estos autores. Igualmente, se podrá valorar la modernidad del pensamiento agustiniano y su vigencia siglos después de su época, no sólo en el ámbito teológico, sino también en el literario y estético.
\end{abstract}

PALABRAS CLAVE: San Agustín; Wackenroder; C. D. Friedrich, Novalis; Romanticismo; Estética.

\section{Saint Augustine and the romantic aesthetics}

ABSTRACT: This article proposes possible connections between the Augustinian mysticism and the aesthetic thought of St. Augustine, with the main basis of German Romanticism represented by three authors, Wilhelm Heinrich Wackenroder and his text Confessions of a monk in love with art, Caspar David Friedrich and his painting Monk facing the sea, and Novalis and his lyrical, narrative and essays. In this way, it is sought to leave open another possible way of approaching the romantic movement and knowledge of its ideals that could complete the perspectives from which the lives and works of these authors have been already studied. Similarly, it could be assessed the modernity of Augustinian thought and its validity centuries after its time, not only in the theological aspect, but also in the literary and aesthetic.

KEY WORDS: Saint Augustine; Wackenroder; C. D. Friedrich; Novalis; Romanticism; Aesthetics.

Si nuestra memoria busca una imagen para ilustrar el término Romanticismo, quizá ponga ante nuestros ojos del recuerdo la figura de un monje dándonos la espalda, detenido frente al mar en una playa desierta. Probablemente, esta pintura de Caspar David Friedrich, Monje frente al mar (1810) [Fig. 1], es sino la más, al menos si una de las más significativas de la pintura romántica alemana, convertida casi en icono de este movimiento, y no ya sólo en el país germano, pues en ocasiones parece condensar en sí misma buena parte del espíritu de los románticos.

Este será el primer icono presentado en este estudio, cuya intención es la de ofrecer aquellos indicios que puedan servir para vincular a San Agustín con el alma romántica. Para ello, si buscamos un referente iconográfico antecesor de aquella imagen de Friedrich, será éste el primer momento en que nos encontremos con el Hiponense, igualmente apostado a orillas del mar, vestido de negro con su hábito de monje, como aquel hoy visible en los Staatliche Museen de Berlín, meditando acerca de uno de los temas más complejos de la teología, el Misterio de la Santísima Trinidad. Esta representación de San Agustín [Figs. 
2 y 3] corresponde al relato aparecido en La leyenda Dorada de Jacobo de la Vorágine $^{1,}$ una de las fuentes más utilizadas a la hora de dotar de figura al santo en la iconografía cristiana.

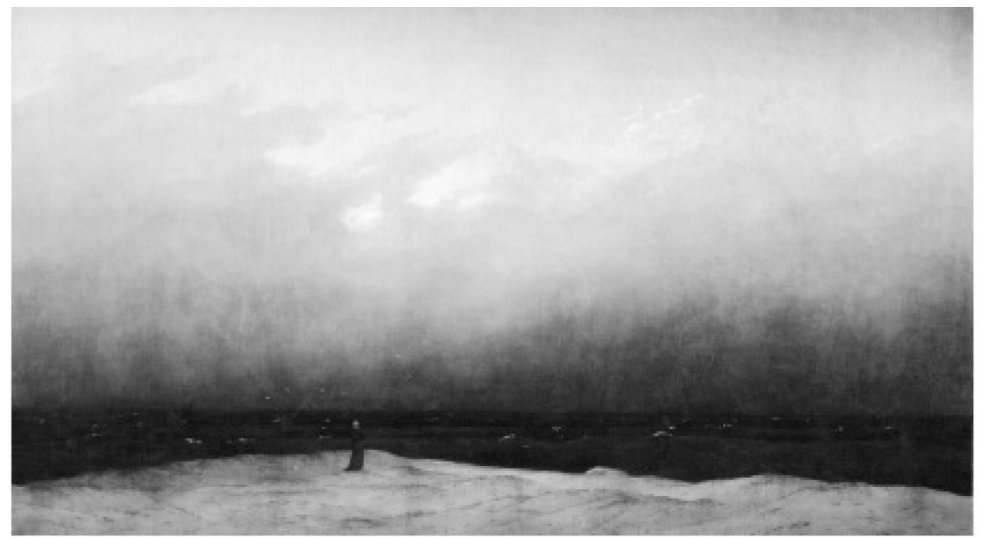

[Fig. 1] Monje frente al mar (1810).

Caspar David Friedrich. Staatliche Museen, Berlín
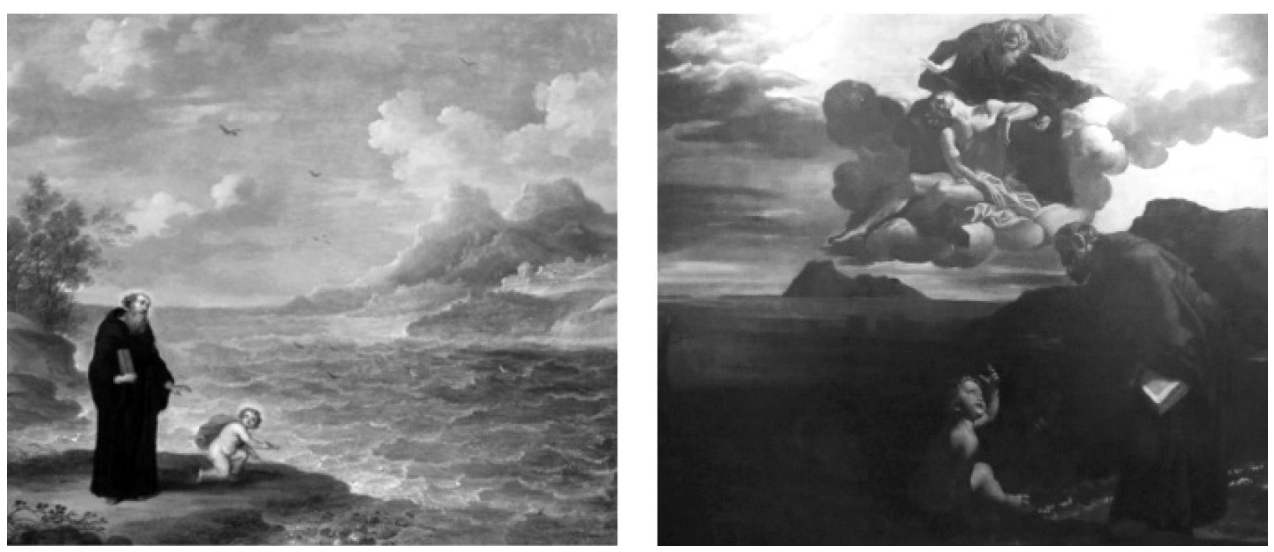

San Agustín meditando sobre el misterio de la Santísima Trinidad.

[Fig. 2] Atribuído a Abraham Willemsens (1610-1672), col. Privada

[Fig. 3] 1616, Giovanni Lanfranco, iglesia de San Agustín, Roma

1 Leyenda Dorada o Leyenda Áurea, es el conjunto de relatos hagiográficos reunidos por el dominico Santiago de la Vorágine (1228-1298), y relativos a 180 santos y mártires cristianos, basados en los Evangelios, los Apócrifos, y escritos de Casiano y Jerónimo de Estridón, entre otros. Un texto original en latín, que con la aparición de la imprenta fue muy difundido en diversos idiomas a finales del siglo XV, no solamente como libro de lectura, sino también como manual de iconografía para los pintores de la Edad Media, del Renacimiento y del Barroco. La leyenda sobre San Agustín cuenta cómo en una playa se ve interrumpido en sus meditaciones sobre la Santísima Trinidad por la visión de un niño que intenta meter el agua del mar en un agujero. El santo le hacer ver la dificultad de esta pretensión, a lo que el niño (presuntamente el Niño Jesús) le responde cómo es igual de difícil comprender el misterio de la Trinidad. 
De esta manera, es posible enunciar ya, a modo introductorio, un punto de unión, sobre el que profundizaremos después, entre San Agustín y el Romanticismo. El segundo de los tres indicios que nos proponemos abordar viene de mano de la literatura. Para estudiosos y expertos en el Romanticismo alemán existe una pequeña obra, no por ello de menor importancia, cuyo texto podría considerarse uno de los principales puntos de arranque para el Romanticismo en este país ${ }^{2}$. Pertenece al género literario de la confesión, término ineludiblemente próximo a San Agustín, pues él inauguraba dicha modalidad literaria con sus Confesiones. El libro fue escrito por Wilhelm Heinrich Wackenroder, editado después de la muerte del autor, en 1797, por su íntimo amigo Ludwig Tieck, bajo el título Confesiones de un monje enamorado del arte. Se trata de una recopilación de reflexiones en torno al arte puestas por escrito por el joven esteta tras la figura de un monje ficticio, supuesto autor de esas páginas. $\mathrm{He}$ aquí nuestro segundo lugar de encuentro. Aproximémonos ahora al tercero en cuestión.

En no pocas ocasiones la representación de San Agustín atiende a otras tipologías iconográficas donde destacan dos atributos identificadores de su persona. En una aparece acompañado por una construcción arquitectónica; y en la otra, portando un corazón en llamas, bien albergándolo en el pecho o sosteniéndolo en la mano.

El primero de los motivos hace referencia a su obra La Ciudad de Dios, y el segundo - protagonista del emblema de la orden agustiniana - es, según Johannes Molanus, símbolo de su total entrega a Dios ${ }^{3}$. El atributo se inspira en dos puntos de su obra. Por un lado, puede deberse a uno de sus comentarios al capítulo 23 de los Proverbios, en el cual se dice: Dame hijo tu corazón y que tus ojos hallen deleite en mis caminos ( $\mathrm{Pb} 23,26)$. Y por otro, haría referencia a esta frase de sus Confesiones: «Tus flechas habían atravesado mi corazón con tu amor. Llevaba tus palabras clavadas en mis entrañas $»^{4}$, hipótesis barajada a partir de la frecuencia con que desde el siglo XVI una flecha traspasa su corazón en las imágenes que lo representan. Este corazón será el tercer punto de concurrencia entre nuestros autores románticos y San Agustín.

El protagonismo concedido al corazón humano en la imaginería agustiniana ha llegado incluso a provocar la creación de una terminología para referir conjuntamente las reflexiones teológicas y espirituales del santo sobre esta parte del hombre, se trata de la philosophia cordis, «filosofía del corazón». Denominación acuñada por el teólogo Anton Maxsein, quien realizó estudios sobre el lugar central que ocupa el corazón en el desarrollo de la teología y de la personalidad del Hiponense. Un término —cor-que Clement Louis Hrdlicka

\footnotetext{
2 Sirva de ejemplo el autor Richard Benz que en su Die deutsche Romantik comienza su libro afirmando rotundamente que «Wackenroder fundó el Romanticismo». BEnz, R., Die deutsche Romantik. Philipp Reclam, Leipzig 1937, p. 12. (Traducción propia).

3 Molanus, J., de Historia SS. Imaginum, Lovaina, 1570. Citado en: Carmona Muela, J., La iconografía de los santos. Itsmo, Madrid 2003, p. 16.

4 San Agustín, Confesiones. IX, 2, 3.
} 
(OSB) traducía por «alma», una concepción muy parecida a la de A. Guillaumont, quien lo interpretaba como el equivalente lírico de «ánima», alejándolo de la categoría de facultad meramente afectiva, para interpretarlo como el medio por el cual «se realiza para el alma la presencia de Dios $»^{5}$ relacionándose, en ambos ejemplos, con la que se ha llamado «mística agustiniana», y, en cualquier caso, con la piedad ardiente que se refleja en sus Confesiones.

En ellas encontramos un espacio dedicado a este rincón del interior humano, bajo el nombre «El retorno al corazón», seguido por una sección titulada «Qué es la belleza». Corazón y belleza aparecen íntimamente relacionados así, en las primeras confesiones de la historia de la literatura, las del monje Agustín. Una intensa y estrecha relación que domina también las confesiones escritas por nuestro humilde monje romántico.

Cuántas veces no se atribuye al Romanticismo el haber despertado a los sentimientos humanos, tras su letargo durante los dominios de las luces de la razón durante la Ilustración, y qué lugar ha sido siempre en el imaginario colectivo el más recurrente para ubicar dichos sentimientos, de toda índole y condición, sino el corazón. Y si entre las páginas de algún poeta romántico alemán podemos vislumbrar análogas llamas a las refulgentes en el corazón agustiniano, es entre las de Novalis, tanto en sus Himnos a la noche, como en sus Cánticos espirituales, o en su Enrique de Ofterdingen. Por otra parte, es en él mismo en quien podemos detenernos para encontrar cierta proximidad de pensamiento entre La Ciudad de Dios, de San Agustín, y una obra literaria romántica, como es el ensayo de Novalis titulado La Cristiandad o Europa.

Así pues, San Agustín se da cita con nuestros autores en la confesión, recogido en la celda, descubriendo en su intimidad el amor a la belleza de las cosas divinas y humanas; a orillas del mar, detenido en una playa meditando en soledad; y en el ardor de un corazón enamorado de la creación, de la poesía, y sin temor a la muerte.

Comenzaremos nuestro peregrinar a lo largo de esta «trinidad» de autores y sus obras de la mano del santo, acercándonos en primer lugar a aquellas Confesiones del monje enamorado del arte de Wackenroder. Escogemos para iniciar este camino dos fragmentos, uno de cada autor, donde puede constatarse la proximidad entre sus pensamientos, sobre todo en lo referido a la naturaleza y la belleza.

El Creador que hizo nuestra tierra y todo lo que está sobre ella, la abarcó con su mirada y vertió el río de su bendición sobre todo el orbe. Desde su misterioso taller, esparció sobre nuestro globo miles de cosas infinitamente diversas que dan frutos infinitamente distintos y que brotan rápidamente en su honor en el jardín más grande y colorido. Maravillosamente guía su sol en círculos medidos. [...] Con ojo ecuánime se fija en un gran momento sobre

5 Peza, E. de la, (SJ) «El significado de “cor” en San Agustín», en: Études Agustiennes, vol. VII, $\mathrm{n}^{\circ} 4$, (1961), pp. 339-368, p. 341. 
la obra salida de sus manos y recibe con complacencia la obra de toda su naturaleza 6 .

Todas esas cosas le alaban, en quietud y movimiento, en lo más humilde de la tierra y en lo más alto de los cielos, en la antigüedad y en la renovación. Cuando ves estas cosas, te alegras, te elevas a su Artífice y contemplas con el entendimiento lo invisible por lo visible... Si hermosas son las obras, ¿cuánto más lo será quien las hizo? ${ }^{7}$.

Aun separados por casi quince siglos, los sentimientos de estos hombres frente a la naturaleza y la conciencia de una mano creadora tras ella, resultan notablemente análogos. Nos sirven para adentrarnos en el conocimiento de nuestras confesiones románticas partiendo no ya sólo desde el punto de vista literario, sino también desde la perspectiva del espíritu con que fueron escritas respecto a la contemplación de la naturaleza, el arte y sus bellezas.

En el relato de Wackenroder, tal como dijimos, la primera persona que deposita sus pensamientos en confesión al lector es la presunta mano de un monje. Este alter ego de nuestro autor escribe el libro en la celda de su monasterio, donde ha terminado llegando desde su frustrada vocación de pintor. No descontento por ello, muy al contrario, una vez acogida su vocación a la vida monástica, decide escribir sus impresiones e ideas respecto al arte, sobre todo acerca de la pintura:

En la soledad de mi vida monacal, desde la que sólo de vez en cuando pienso en el lejano mundo, han ido naciendo poco a poco las siguientes disertaciones $^{8}$.

Y lo hace con la intención de ayudar a todo joven a quien llegue el humilde texto y esté interesado por iniciarse en este arte durante aquellos últimos años del siglo XVIII.

El libro está dividido en capítulos, pero sin presentar deseos de erigirse como un tratado al uso, o un sistema estético ordenado, sino con la aspiración de ir constituyéndose en un lugar donde las ideas del autor puedan fluir tal como le brotan, en correspondencia a la palabra alemana empleada en el título original — traducible al castellano por «confesiones»-, pues se trata, de forma literal, de «efluvios del corazón de un monje enamorado del arte» («Herzenergießungen eines kunstliebenden Klosterbruders») ${ }^{9}$.

De este mismo modo nacen las declaraciones de San Agustín en sus propias Confesiones, desde lo más íntimo de su ser, por primera vez aquí en la historia de la literatura. En una de las referencias más citadas de esta obra, podemos encontrar destellos que siguen haciendo dirigir nuestra mirada a los tres autores románticos aquí estudiados.

\footnotetext{
6 WACKENRODER, W. H., Efluvios cordiales de un monje amante del arte. Con una reseña de August Wilhelm Schlegel. KRK Ediciones, Oviedo 2008, pp. 129-130.

7 San Agustín, Enarrationes in Psalmos., CXLVIII, n. 15. Citado en: Antuna Rey, L., Qué es lo bello. Introducción a la estética de San Agustín. Instituto Luis Vives de filosofía, Madrid 1945, p. 183.

8 WACKENRODER, op.cit., n. 6, p. 65.

$9 \quad$ Este es el título íntegro en el alemán original.
} 
¿Qué es lo que amo cuando te amo a ti? No una belleza corpórea, ni una armonía temporal, ni el brillo de la luz, tan apreciada por estos ojos míos; ni las dulces melodías y variaciones tonales del canto ni la fragancia de las flores, de los ungüentos y de los aromas, ni el maná, ni la miel, ni los miembros atrayentes a los abrazos de la carne. Nada de esto amo cuando amo a mi Dios. Y, sin embargo, amo una especie de luz y una especie de voz, y una especie de olor [...] cuando amo a mi Dios, que es luz, voz, fragancia, comida y abrazo de mi hombre interior. [...] ¿Y qué es esto? Pregunté a la tierra, y me respondió: "no soy yo". Idéntica confesión me hicieron todas las cosas que se hallan en ella. Pregunté al mar, a los abismos y a los reptiles de alma viva, y me respondieron: "nosotros no somos tu Dios. Búscalo por encima de nosotros" [...]. Pregunté al cielo, al sol, a la luna y a las estrellas. "Tampoco nosotros somos el Dios que buscas", respondieron. [...] Acto seguido, me dirigí a mí mismo y me pregunté: “¿Y tú quién eres?” Yo contesté: “Un hombre”. Aquí me tienes equipado de un cuerpo y de un alma, el uno exterior, la otra interior. ¿A cuál de los dos preguntarle sobre mi Dios? [...] Indudablemente el elemento interior es más selecto. [...] El hombre interior aprendió todo esto con auxilio del hombre exterior. Yo, el interior he aprendido esto. [...] Trascenderé esta fuerza de mi naturaleza [los sentidos], para escalar gradualmente hasta mi Creador.

[...] El caso es que tú estabas dentro de mi y yo fuera. Y fuera te andaba buscando y, como un engendro de fealdad, me abalanzaba sobre la belleza de tus criaturas. Tú estabas conmigo, pero yo no estaba contigo. Me tenían prisionero lejos de ti aquellas cosas que, si no existieran en ti, serían algo inexistente. Me llamaste, me gritaste, y desfondaste mi sordera. Relampagueaste, resplandeciste, y tu resplandor disipó mi ceguera. Exhalaste tus perfumes, respiré hondo, y suspiro por ti. Te he paladeado, y me muero de hambre y de sed. Me has tocado y ardo en deseos de tu paz ${ }^{10}$.

Estas palabras recogen ya conceptos fundamentales en el Romanticismo: trascendencia, hombre interior, subjetivismo, sentimientos, emociones, belleza, o naturaleza. Provienen, como decíamos, de lo más profundo del corazón de un hombre, nos hablan de una especial belleza, de la trascendencia determinante que para él poseen las cosas del mundo, de lo divino, de Dios, y de las aspiraciones más íntimas de su alma. No parece resultar descabellado plantear entonces la posible adopción de estas palabras por un romántico. Sirva de ejemplo la descripción que hace el filólogo estadounidense Andrew Weeks de la contraposición entre la «entusiasta introspección filosófica y apasionado deseo de creer», de San Agustín, a la que llega a calificar como anticipo de la transición entre el racionalismo kantiano y el misticismo romántico ${ }^{11}$.

Es en estas dos últimas palabras —misticismo romántico- donde encontramos una importante clave para comprender cuál es el centro en que se reúnen las líneas trazadas no sólo por San Agustín y Wackenroder, sino también junto a ellos por Friedrich y Novalis. Sirva apuntar que autores como Przywara

10 San Agustín, op. cit., n. 4, X, 6, 8 y X, 27, 38.

11 Weeks, A., German mysticism. From Hildegard of Bingen to Ludwig Wittgenstein. A literary and intellectual history. State University of New York Press, Nueva York 1993 p. 32. (Traducción propia). 
o López Pulecio ${ }^{12,}$ llegan a referirse al romanticismo ${ }^{13}$ del santo africano, un rasgo que incluso según Gabriela Maturo «caracteriza la amplia tradición del cristianismo desde San Agustín en adelante» ${ }^{14}$.

Y es que, a pesar de que las páginas de Wackenroder constituyen un libro, podríamos decir, de estética de la pintura, están transidas de un notable misticismo, evidencia justa del motivo por el cual nuestro autor elige a un monje para poner por escrito sus pensamientos sobre el arte.

Desde mi más temprana juventud, cuando conocí por primera vez al Dios de los hombres en los antiquísimos libros sagrados de nuestra religión, la naturaleza me resultó siempre el más minucioso y claro libro de interpretaciones sobre su ser y sus propiedades. El susurro en las cimas del bosque y el retumbar del trueno me han narrado cosas tan misteriosas de Él, que no puedo expresarlas con palabras. Un bello valle, rodeado de rocas singulares, un río cristalino, sobre el que los árboles se reflejan inclinados, o un sereno prado verde, iluminado por el cielo azul — ah, estas cosas han provocado las más maravillosas emociones en lo más íntimo de mi ánimo, han insuflado cordialmente en mi espíritu la omnipotencia y la bondad perfecta de Dios, y purificado y elevado toda mi alma mucho más de lo que podrá hacerlo jamás el lenguaje de las palabras-.

\section{[...]}

He aquí una gran ocasión para elogiar el poder y la bondad del Creador. En torno a nosotros, los hombres, colocó una infinita cantidad de cosas, de las cuales cada una tiene una esencia distinta y de las cuales no entendemos ni comprendemos nada. No sabemos lo que es un árbol, lo que es un prado, lo que es una roca; no podemos hablar con ellos en nuestro idioma; sólo nos entendemos entre nosotros. Y, sin embargo, el Creador puso en el corazón del hombre una simpatía tan maravillosa por estas cosas, que ellas le conducen por caminos desconocidos a sentimientos o convicciones, o como se los quiera llamar, que nunca alcanzaríamos por medio de las palabras más medidas ${ }^{15}$.

Y si estas palabras necesitan apoyo, podemos encontrarlo recurriendo al testimonio de su más íntimo amigo, Ludwig Tieck:

Mi amigo buscaba recoger en este libro nuestros pensamientos y su íntimo amor al arte. Escogió deliberadamente la máscara de un monje para poder expresar con mayor libertad su carácter piadoso y su devoto amor por el arte ${ }^{16}$.

12 López Pulecio, O., Palabras necias. Universidad del Valle, Colombia 2005, p. 125. Przywara, E., San Agustín. Perfil humano y religioso. Ediciones Cristiandad, Madrid 1984, p. 62.

${ }_{13}$ Incluso Víctor Hugo lo menciona en su Manifiesto romántico. Hugo, V., Manifiesto romántico. Escritos de batalla. Ediciones Península, Barcelona 2009, p. 35.

14 Maturo, G., Marechal, el camino de la belleza. Biblos, Buenos Aires 1999, p. 100.

15 WaCKenRODER, op. cit., n. 6, pp. 154-156.

16 Epílogo en: WaCKENRODER, W. H., Herzensergießungen eines kunstliebenden Klosterbruders. (Bollacher, M., ed.) Philipp Reclam, Stuttgart 2013, p. 179. 
Pero para atender a esta realidad mística y estética de nuestro autor, conozcámosle algo mejor. Nacido en una familia pietista alemana, a su padre debe la transmisión de la fe familiar, en la cual profundizará durante sus años de estudiante acompañado de Tieck y también de un creciente interés por el arte. Los dos amigos recorrerán diversas ciudades durante sus años de estudiantes en la universidad de Erlangen, así visitaron Jena, Weimar y Erfurt, donde comenzaría a gestarse el gusto de ambos por la arquitectura y el arte gótico, así como su conocimiento de la vida monástica, al visitar juntos por primera vez, en esta ciudad, un monasterio, el que fuera residencia de Lutero entre 1505 y 1512.

Aunque Wackenroder fue destinado a Erlangen para estudiar derecho, asistía junto a Tieck a sus clases de literatura. Ya antes de iniciar sus estudios universitarios, sus intereses en las artes no eran desdeñables. Sentía por la música una especial predilección, ocupando en ella gran parte de sus horas de estudio gracias al apoyo Friedrich Reichardt, compositor, crítico musical y maestro de cámara de la corte prusiana, íntimo amigo de Goethe. A ello se sumaron las lecciones sobre Arqueología e Historia del Arte de Karl Philipp Moritz, cuya influencia puede intuirse en afirmaciones como la que Wackenroder hace a su amigo Tieck en una de sus cartas acerca de la facultad creadora de los artistas, faceta ensalzada por Moritz en sus escritos al afirmar: «el artista, el poeta, es creador ${ }^{17}$; así como en su concepción del arte como un lenguaje especial, para Moritz «un lenguaje superior» ${ }^{18}$, que expresa aquello imposible de traducir en palabras. Le diferenciará, sin embargo, del pensamiento de su profesor el considerar la obra signo de trascendencia divina, y no solamente generadora de puro placer estético, pues "el acto creador nos habla de lo divino» ${ }^{19}$. Este hecho será uno de los principales acicates — junto a su sensibilidad y predisposición personales y el apoyo de Tieck- de su constante interés por las artes plásticas.

Una curiosidad alimentada con el recorrido por numerosas catedrales y edificios góticos como la catedral de Bamberg, o las iglesias de Nürnberg, ciudad natal del que se convertirá, junto con Rafael, en uno de sus artistas predilectos: Alberto Durero. Tampoco descuidarán la visita a importantes galerías de pintura como la que contenía en aquel entonces el Castillo de Pommersfelden.

En estos periplos comienza a familiarizarse no únicamente con el arte, sino también con otra realidad a la que llega a partir de éste: el Catolicismo, pues, de hecho, las impresiones que recoge durante su primer viaje a Bamberg testimonian incluso en este caso un mayor impacto sobre él del mundo católico, que del arte. Wackenroder expresa en sus cartas un singular deseo por visitar esta ciudad para contemplar una procesión. Lo verá cumplido, asistiendo no solamente a una procesión, sino también a la celebración de una Misa católica, con cuya liturgia y actitud de los fieles queda fascinado. En su paseo por las

17 Kahnt, R., Die Bedeutung der bildenden Kunst und der Musik bei W.H. Wackenroder. N.G. Elwert Verlag, Marburg 1969, p. 22

18 Aspiunza, J., «La naturaleza en Über die bildende Nachahmung des Schönen, de Karl Philipp Moritz», en: Contrastes. Revista internacional de filosofía, vol. XV (2010), pp: 26-42, p. 41.

19 KAHNT, op.cit., n. 17, p. 31. 
diferentes iglesias adquiere la conciencia de no disfrutar como le gustaría de las obras de arte guardadas en ellas, pues afirma en sus epístolas desconocer la naturaleza inconográfica de los temas, sintiendo la necesidad de formarse en ellos para poder percibir la belleza artística que en estos momentos comienza a descubrir.

A esta experiencia se añade otra esencial para la construcción posterior de su alter ego a partir de la figura del monje, y es que podrá acercarse a conocer algunos de los más significativos monasterios de la ciudad, los cuales visita con la más «ardiente curiosidad $»^{20}$. En este recorrido es guiado por alguno de los monjes allí consagrados, y recorre con ellos sus bibliotecas, dependencias, iglesia, capillas, al tiempo que conocerá de este modo sus costumbres, sus modos de vestir, de actuar y las rutinas de su vida diaria.

En otoño de 1793 los dos amigos decidieron continuar sus estudios en la universidad de Gotinga. Cuando Wackenroder llega aquí, sus clandestinos estudios literarios le habían convertido también ya en un experto filólogo autodidacta, con conocimientos sobre todo de la literatura medieval alemana.

Gracias a esta nutrida y completa formación realizará sus primeras incursiones en el mundo literario, escribiendo algunos ensayos sobre los temas recién descubiertos como Schilderung der dramatischen Arbeiten des Meistersängers Hans Sachs (La Historia de los dramas del Meistersinger Hans Sachs), y Über die Minnesänger (Sobre los Minnesinger). Incluso colaborará con su profesor, E. J. Koch, en la elaboración de un compendio sobre literatura alemana titulado Compendium der deutschen Litteratur-Geschichte.

En Gotinga continúan sus aproximaciones a la teoría del arte junto al historiador Johann Dominique Fiorillo (1748-1818), pintor y profesor de dibujo. Sus lecciones no sólo fueron importantes para Wackenroder, pues entre sus alumnos se contaron también el mismo Tieck y A. W. Schlegel.

Junto a su formación literaria y artística, no hay que dejar de lado su perseverancia en los estudios sobre música. Prosiguió su aprendizaje recibiendo clases de Johann Nikolaus Forkel (1749-1818), historiador de música especialista en J. S. Bach, al mismo tiempo que lecciones de piano, alcanzando conocimientos suficientes para componer sus personales, aunque pequeñas y modestas, piezas musicales. Esta inclinación y conocimientos serán los que se desahogarán en la segunda parte de sus Confesiones, dedicadas a un supuesto amigo del monje, el músico Joseph Berlinger.

Su siempre creciente interés por las artes se reflejará además en un proyecto tejido junto a su amigo Tieck. Planearon realizar un viaje a Roma, para dedicarse allí juntos cada uno a la que sentían como su vocación: la música para Wackenroder y la literatura para Tieck. Pero la realidad, en forma de voluntad paterna y servicio al estado, le llamaba, y el idílico proyecto quedó en agua de borrajas. Al año siguiente, en 1794, tanto Tieck como Wackenroder regresan

$20 \quad$ Ibid., p. 48. 
a Berlín, donde, inevitablemente, comienza la tediosa carrera de funcionario para el segundo.

Será en esta época cuando comience a dedicarse más plenamente a su manuscrito Herzensergießungen eines kunstliebenden Klosterbruders, cuya redacción había iniciado ya durante sus estancias en Erlangen y Gotinga, a partir de todas las experiencias relacionadas con el arte acumuladas hasta el momento.

Así, acabamos de repasar la que podríamos llamar «educación estética del monje», tomando la idea de una obra publicada por Schiller en fechas próximas a las Confesiones. La educación estética del hombre. De este modo se fragua el corazón de donde emergerán esos efluvios sinceros, espontáneos, confesiones con el orden, sin mucho concierto, propio al nacer del deseo no fácilmente dominable de poner en conocimiento de un interlocutor lo que de otro modo se teme perder si no se le da forma, bien sea de palabra escrita o pronunciada.

El confesante, el autor en nuestro caso, poniendo al descubierto sus sentimientos y pensamientos más personalísimos, alberga un deseo cuyo protagonista no es otro sino el propio confesor, aquí el lector. Una dinámica descrita de modo claro por María Zambrano en su ensayo sobre este género literario:

Cuando leemos una confesión auténtica, sentimos repetirse aquello en nosotros mismos, y si no lo repetimos, no logramos la meta de su secreto, necesita ser actualizado. [...] La confesión leída, si no es en balde, tiene que verificar aquello mismo que el que ha confesado ha hecho.[...] Mas si no ejecuto lo que ejecutó el autor de la confesión, será en balde su lectura ${ }^{21}$.

Es un fenómeno común y compartido entre, digamos, el maestro de la confesión, San Agustín, y nuestros tres testigos románticos, cada uno "confesándose» con el lector o espectador en sus respectivas obras. Esa respuesta es la pretendida por el monje de papel, encarnado en la propia persona de Wackenroder, el monje de óleo y lienzo salido de los pinceles de Friedrich, y es la reacción deseada también por el místico y apologeta que Novalis construye con su propia obra y personalidad.

El germanista Martin Bollacher ${ }^{22}$ afirma que en la creación de este personaje, reside lo verdaderamente revolucionario del libro, y el mayor acierto de Wackenroder, pues, «¿quién mejor podría oponer diametralmente al clasicismo y al espíritu racional de la época, el principio de la genialidad artística, de la inspiración divina y la defensa de un programa artístico identificado con la fe, que un monje separado del mundo, para el que los fundamentos del arte se encuentran en el ámbito de la experiencia religiosa?» Califica de ingenioso, asimismo, el anacronismo realizado al efecto, pues nos encontramos ante un monje de personalidad casi medieval viviendo en la misma época que Wackenroder, un rasgo, por lo demás, especialmente valorado por el propio A. W. Schlegel, quien dedicó a este texto un extenso artículo en el Allgemeinen Literatur-Zeitung de febrero de 1797, y hacía la siguiente observación:

21 Zambrano, M., La confesión: género literario. Mondadori, Madrid 1988, pp. 17-18.

22 Wackenroder, op. cit., n. 16, p. 179. 
La opinión sobre las bellas artes en la que se basa este agradable escrito no es la habitual de nuestro tiempo. Con razón evitó por ello su anónimo autor el lenguaje de moda y escogió, para encontrar la más viva expresión para su fervorosa sensación de santidad y de la dignidad del arte, un curioso disfraz. [...] Su intención es transmitir a futuros artistas y amantes del arte su respeto rayano en la adoración ante los grandes maestros y oponerse de la forma más enérgica a una especie de conocimiento complaciente que reside más en una lengua pronta que en el interior de espíritu. [...] Esto no es posible sino desprendiéndose de toda presunción vanidosa y entregándose con silencioso recogimiento y afectuosa sensibilidad al alma de la contemplación. El carácter de un monje, para el que el arte, como algo de origen divino, resulta igualmente caro que la religión, para el que éste (el arte) es como un amor religioso o una religión amada: quizá esto es lo más apropiado que se puede encontrar para preparar una disposición semejante, para declamar, con insistencia, doctrinas semejantes ${ }^{23}$.

Cabe preguntarse en este punto si existen indicios en el ámbito de la cultura alemana para rastrear una significativa huella agustiniana a lo largo de su historia que haya podido prolongarse hasta el Romanticismo. Si tomamos como referencia dos nombres señeros dentro de la misma, es posible constatar la existencia de dichas evidencias. Uno ya lo hemos mencionado, Martin Lutero, y el otro es el del místico medieval más destacado de la literatura alemana: Meister Eckhart.

En el momento en que uno se acerca a la cultura e historia alemanas con la vista atenta a todas sus facetas, es decir, filosófica, artística, o literaria, puede comprobarse que una vida convertida en búsqueda incesante de respuestas en, y sobre, la más profunda intimidad del hombre, resulta ser una consecuencia lógica en el carácter del pueblo alemán.

Por un lado, en contraste con la distintiva disgregación latente en este país - confesional primero, territorial después_- el alma del hombre alemán se caracteriza por una fuerte unidad. Los artistas se interesarán por la filosofía, la música y la literatura; los escritores apreciarán las artes, los músicos se inspirarán en las insignes obras de la historia literaria de su nación, mientras que los filósofos tendrán siempre un extraordinario bagaje cultural. No existen de este modo departamentos estanco, o «castas» artístico-culturales, pues a todos ellos les une un punto: el deseo de conocer, de satisfacer los deseos y anhelos más profundos del alma humana.

Y si bien es cierto que, por regla general, en todas las culturas y civilizaciones se produce una infiltración de las corrientes de pensamiento, literarias o artísticas previas en el curso de la historia sobre las posteriores y de las coetáneas entre sí, en el caso de Alemania, parece que esta interacción resulta más patente y evidente. Quizá, en el fondo, buscando compensar así las constantes divisiones y pérdidas de unidad padecidas por este pueblo a lo largo de la historia.

23 Wackenroder., op. cit., n. 4, p. 254. 
Por otro lado, estas circunstancias históricas estuvieron marcadas, y casi podríamos decir conducidas, por las formas en que el hombre tiene experiencia de la fe. Debido a las diferentes y enfrentadas posiciones al respecto, la dimensión religiosa de la vida humana juega un papel fundamental en el desarrollo del pensamiento alemán, desde los orígenes del Sacro Imperio Romano-Germánico, hasta la Reforma protestante y todas sus derivadas. Así es cómo este cariz espiritual, tan presente en el curso de la historia de Alemania, se filtrará con especial trascendencia por los entramados literarios, filosóficos, musicales, convirtiéndose en objeto y sujeto esencial a tener en cuenta para conocer y comprender el desarrollo cultural de este país.

Este esfuerzo por desvelar la cara más íntima y profunda del alma humana será el causante de que, en medio de las diversas y numerosas disensiones de tipo religioso surgidas en Alemania con el paso de los siglos, se mantenga una constante a lo largo de todos ellos, sobre todo desde la Edad Media. Nos referimos a la presencia de la mística en la cultura alemana, a una viva conciencia y experiencia de la tensión hacia lo insondable, misterioso y divino.

El nombre más destacado es, ya lo decíamos, el del fraile dominico Meister Eckhart (1260-1327), y junto al suyo el de dos de sus discípulos, los también dominicos Johannes Tauler y Heinrich Seuse (1300-1366).

El carácter distintivo y definitorio del misticismo alemán será la transformación de los conceptos «yo» y «Tú», — protagonistas de lo que puede definirse como el centro de todo misticismo: una comunicación inefable entre el hombre y Dios- en inmanencia y trascendencia ${ }^{24}$. Es decir, que el intento de la literatura mística de poner por escrito lo experimentado o deseado en una unión entre las personas humana y divina, se transforma para la mística alemana en la pretensión de exponer aquello que envuelve, y en lo que consiste, una unión del mismo carácter misterioso e inenarrable, sólo que en lugar de realizarse entre un "yo» humano y un «Tú» divino, el vínculo extraordinario se produce entre este mundo y el otro, el que vemos, donde vivimos, y el que no vemos, donde habita Dios, del que el hombre cayó y donde espera alcanzar la vida futura. Se amplían así los horizontes de la contemplación humana, pues ya no actúa tanto la mirada dirigida desde el alma individual al Creador, sino la de este mismo espíritu individual sí, pero vivamente consciente de su formar parte de un todo creado en busca de la fuente de su existencia. Quizá sea esta una de las razones por las cuales la naturaleza jugará un papel fundamental dentro de la mística alemana ${ }^{25}$, tanto en la medieval como en la surgida en siglos posteriores.

Al quedar englobados dentro de la mística el hombre, el mundo y Dios, ésta se convierte en, no solamente un medio de comunicación, o mejor dicho de comunión entre el hombre y Dios, sino en un medio de conocimiento, tanto de lo divino, como del hombre y el mundo mismos. Será esta la razón por la

24 WeEKs, A., op. cit., n.11, p. 9.

25 Citemos como ejemplo la obra de la gran mística alemana Hildegard von Bingen (10981179), en la que la naturaleza ocupa un lugar primordial tanto en sus libros propiamente místicos, como en su interés por redactar, al mismo tiempo, escritos de orden científico. 
que el misticismo tendrá tanta repercusión e influencia sobre el desarrollo de la filosofía alemana ${ }^{26}$.

Y si respecto a la «mística agustinana» señalábamos —mediante las referencias paralelas a San Agustín y Wackenroder - el protagonismo del corazón, y, junto a ello, la importancia de la relación entre el alma y la naturaleza, este carácter relacional trascendente entre lo más íntimo del hombre y el mundo, es el mismo eje en torno al cual se desarrollan los pensamientos y experiencias de Eckhart. Es lo que nos confirma de nuevo A. Weeks, al sostener en su estudio sobre el misticismo alemán que «la tradición mística alemana no es solamente bíblica, sino también agustiniana» ${ }^{27}$.

Y es que ha de tenerse en cuenta que la orden dominica a la que pertenecían Eckhart, Tauler y Seuse, vive conforme a la regla de San Agustín, por lo cual resulta lógica la influencia especial del santo africano sobre estos autores. Así se constata tanto en los sermones como en el resto de los escritos de Meister Eckhart, y no sólo en reflexiones y pensamientos concretos, sino también en las abundantes menciones al santo a lo largo de todos sus textos ${ }^{28}$.

A este hecho podemos añadir, por un lado, la afirmación que hace Hans Urs von Balthasar sobre el místico alemán, al considerarle «el padre de la historia del espíritu y de la espiritualidad en la Edad Moderna», habiendo dejado «irradiaciones casi infinitas: en Lutero; pero también en el Cusano, Spinoza, Böhme, Kant, Fichte, Schelling y Hegel» ${ }^{29}$; y, por otro, la que realiza Theo Kobusch cuando explica cómo la influencia de la mística de Eckhart resulta capital el desarrollo de toda la occidental posterior desde Seuse, Tauler ${ }^{30}$, la Theología Deutsch $^{31}$, la tradición mística protestante, V. Weigel, S. Franck, Angelus Silesius, D. Czepko, Francisco de Sales, Madame Guyon, Fénelon, Maine de Brian, hasta llegar a von Baader, o Schopenhauer ${ }^{32}$.

26 WeEKS, A., op. cit., n. 11, p. 11.

27 WeEks., A., ibid., p. 24.

28 Estudios especializados indican que el nombre de San Agustín es el nombre propio mencionado con mayor frecuencia en sus textos, sólo después del de Jesús, encontrándose apenas sermones en donde no se le mencione directa o indirectamente, mucho más incluso que a Santo Tomás, quien pertenecía a su misma orden.

29 Balthasar, H., U., von, Gloria, una estética teológica/5. Metafísica. Edad Moderna. Ediciones Encuentro, Madrid 1996, p. 35. Balthasar constata esta influencia además haciendo referencia a autores que han estudiado el hecho con minuciosidad: Heinrich Maier, Heinz Heimsoeth en Die sechs grossen Themen der Abendländischen Metaphysik, Erich Seeberg, Ernst von Bracken en Meister Eckhart und Fichte, y Gustav Siewerth en Das Schicksal der Metaphysik von Thomas zu Heidegger.

30 En la obra de Tauler el nombre del santo resulta ser del mismo modo el más citado entre sus referencias. WEEKs, A., op. cit., n. 11, p. 97

$31 \quad I b i d$., p. 144. Una de las obras místicas más influyentes dentro de la teología alemana: la Theologia Germanica o Theologia Deutsch, escrita por un autor anónimo a finales del siglo $\mathrm{XIV}$, de la que se conservan ocho manuscritos. Uno de ellos llegó a manos del propio Lutero —quien lo atribuyó en un primer momento Johannes Tauler_, llamando tanto su atención que decidió realizar una edición en 1518 .

32 Kовusch, T., «Mystik als Metaphysik des Inneren», en: VV. AA. Meister Eckhart und Agustinus. Meister-Eckhart-Jahrbuch, Vol. 3. W. Kohlhammer Verlag, Freiburg 2011, pp. 1737 y p. 20. 
Con todos estos factores, podría darse el salto necesario para establecer el hilo conductor desde San Agustín, de quien todos los autores referidos han podido recibir semblanzas por medio de Eckhart, hasta el Romanticismo alemán, pues la sucesión de la obra de estos mismos se prolonga en el tiempo hasta la aparición del movimiento.

Además de Eckhart, como decíamos y acaba también de apuntar von Balthasar, Lutero será él el otro canal que contribuirá a la «infiltración» del espíritu del Hiponense en la filosofía alemana. No ha de olvidarse que su pertenencia a la Orden de San Agustín abarca desde 1505 hasta su salida de la Iglesia Católica en 1521. Por ello, en 1518, llegaba a escribir que las fuentes de las que más había aprendido eran tres: la Biblia, la obra de San Agustín y la Theologia Deutsch.

Y en segundo lugar, resulta muy importante la incidencia directa de la obra de San Agustín sobre la formación de los continuadores de la Reforma en sus diversas vertientes, como es el caso de Thomas Müntzer (1490-1525); o August Francke, a cuya conversión ${ }^{33}$ contribuyó de forma destacada la obra de nuestro primer monje negro, al igual que sobre la mística de Gerhard Tersteegen (1697$1769)^{34}$.

Teniendo en cuenta ambas líneas de influencia agustiniana en el desarrollo del pensamiento alemán, nos disponemos a exponer, en primer lugar, una selección de los puntos esenciales de conexión entre Meister Eckhart y San Agustín, y que serán los que lleguen desde el santo hasta la mística alemana posterior. Para escogerlos, el criterio seguido ha sido elegir además aquellos más próximos al ideario estético del Romanticismo alemán, y que más luz puedan aportar a este estudio. Por otro lado, señalaremos aquellas otras reflexiones vertidas por el Hiponense, también rayanas con el movimiento romántico alemán, que pudieron ir alcanzando de algún modo el pensamiento de significativos representantes de la cultura alemana, cuyos vestigios parece llegan a respirarse en época de nuestra tríada romántica.

El punto de conexión más importante entre Meister Eckhart y San Agustín es la especial atención puesta por el místico alemán en la interioridad del hombre, al igual que lo hacía el santo africano, como lugar dónde Dios se hace presente primordialmente y se acerca a su criatura, siendo esta inhabitación filial y cercanía el objetivo de la creación, carente de sentido desprovista de este fin ${ }^{35}$.

Así afirma San Agustín que «Dios es el sol de las mentes. [...] La mismísima luz con que el alma es alumbrada para verlo todo con una verdadera comprensión en sí misma o en aquella luz» ${ }^{36}$. Sucede sólo una cosa, que «Él [Dios] ha hecho todas las cosas y no está lejos. Pues no las hizo y se marchó, sino que

\footnotetext{
33 WeEKs, op. cit., n. 11, p. 194.

34 Ibid., p. 201.

35 Büchner, Ch., "Non enim fecit atque abiit, sed ex illo in illo sunt. Schöpfung und Innerlichkeit bei Augustinus und Meister Eckhart», en: VV. AA., op. cit., n. 32, pp. 73-87, p.

36 Balthasar, H. U., von, Gloria. Una estética teológica/2. Estilos eclesiásticos. Ediciones Encuentro, Madrid 2007. p. 100.
} 73. 
proceden de Él y están en Él [...]. Está en lo más íntimo del corazón, pero el corazón se ha ausentado lejos de Él» ${ }^{37}$.

Esto es lo que deja escrito el Hiponense en sus Confesiones cuando habla del «retorno al corazón», idea presente también en De Trinitate, y citada a través de referencias a ambas obras por el propio Eckhart, que, parafraseando a San Agustín, afirmaba que «quam nemo invenit, qui eam foris quareit» (no encuentra la verdad quien la busca fuera), porque «verus est in anima, non extra in rebus» ( «la verdad está en el alma, y no fuera en las cosas» ${ }^{38}$ ). Veamos cuánto se acerca esta idea de Eckhart a otras palabras del Hiponense, extraídas también de dicha obra:

Mas tú, amor mío, ante quien me siento extenuado para ser fuerte, no eres ninguno de estos cuerpos que contemplamos, [...] porque eres el creador de todos ellos. [...] Tampoco eres el alma, que es la vida de los cuerpos, y la vida de los cuerpos es más excelente y más real que los cuerpos mismos. Tú eres la vida de las almas, la vida de las vidas, [...] vida de mi alma. [...] Dios mío, reconozco que me llegó tu compasión cuando aún no te confesaba, [...] tú me eras más íntimo que mi propia intimidad y más alto que lo más alto de mi $\operatorname{ser}^{39}$.

En el texto autobiográfico de su «maestro», como le llamaba, buscaba Eckhart las respuestas a las cuestiones acerca del significado y la interpretación de las Escrituras, a sobre cómo habría que definir a Dios, describir la situación real del hombre en el mundo, plantear la conducta humana respecto a la libertad y la gracia, o a la relación entre la temporalidad del hombre y la eternidad de Dios. Vamos así comprobando el notable valor de San Agustín para Eckhart como lugar donde encontrar inspiración para expresar su sentimiento místico.

A lo largo y ancho de toda su obra, y en esta misma línea de proximidad entre ambos autores, es decir, la del itinerario del hombre hacia su interior para encontrarse con Dios, existen otros ejemplos, evidencias de la confianza puesta por San Agustín en la existencia de una vía dentro del hombre capaz de conducirle hacia lo divino. Resultan estas referencias sumamente interesantes, pues el planteamiento de dicha senda hacia la transcendencia divina es muy similar al seguido después por nuestros autores románticos. Una trayectoria así descrita por estas palabras del santo:

Quien de camino hacia la sabiduría mira y considera la totalidad de la creación, siente cómo se revela amorosamente la sabiduría en el camino y le sale al encuentro en cada providencia, y con mayor fervor arderá en el deseo de recorrer el camino cuanto más bello se lo hace la sabiduría por cuya consecución ansía ${ }^{40}$.

37 San Agustín, op. cit., n. 4, IV, 12, 18.

38 Fischer, N., "Meister Eckhart und Agustinus Confessiones», en: VV. AA., op. cit., n. 32, pp 196-219 y p. 201.

39 San Agustín, op. cit., n. 4, III, 6, 11.

40 San Agustín, Libero arbitrio 2, 45. Citado en: Balthasar, Hans Urs von, op. cit., n. 36, p. 102. 
Y cuánto más con estas otras que citamos a continuación, claves sobre cómo dotar de sentido al encuentro del hombre con la creación, insistiendo en la imposibilidad de encontrar a Dios en las cosas, pero sí a través de las cosas. No se trata de rechazar las formas del mundo sensible, sino de profundizar en ellas y dar con su verdadero valor.

No hay que contemplar infructuosamente y en vano la belleza del cielo, el orden de los astros, la fuerza irradiante de la luz, la alternancia de días y noches [...], sino que debe ser una escala para llegar a lo inmortal y sempiterno ${ }^{41}$.

Recorre con tu espíritu todas las criaturas; en todas partes te darán voces diciendo: Dios nos ha creado todo lo que te deleita en el arte, redunda en honor del artífice: cuanto más recorras las criaturas, su contemplación te hará prorrumpir en alabanza del Artista. Contempla los cielos: iqué maravillosa obra de Dios! Ves la tierra: Dios creó las formas de las semillas, la variedad de los gérmenes, la multitud de los animales. Repasa con tus ojos los cielos y la tierra: todo está pregonando la gloria de un Hacedor; las mismas hermosuras de las criaturas son ciertas voces que están alabando a su Creador ${ }^{42}$.

Encontramos aquí además la inclusión de un interesante concepto: «la belleza del arte». Y es que para San Agustín la belleza de todas las cosas creadas, también las creadas por el hombre, constituye un medio para entrenar el alma, purificarla de todo apego sensual, ejercitando la costumbre de contemplar esta belleza del mundo como pálido reflejo de la belleza divina de la que algún día gozará. Esta purificación y ordenación, implica asimismo la transformación del alma en un alma bella, en comunión con la hermosura de lo contemplado, y que será peldaño fundamental en esta escala hacia lo eterno. Vemos así como la teoría estética de San Agustín contiene una gran implicación antropológica, al igual que la romántica.

Sin embargo, para que el hombre vea tendida ante sí dicha escala ha de tener presente que «esta visión se logra sólo si la vista contemplativa ha sido ya reforzada y alumbrada por la fe, la esperanza y el amor ${ }^{43}$, disponiendo al hombre a descubrir que el mundo es un «bellísimo espectáculo de contemplación para rastrear por su hermosura, su utilidad y potencia las grandezas invisibles del Hacedor» ${ }^{44}$, capacitándole para leer el universo "como un poema donde las estrofas y las sílabas tienen que sucederse para producir todo su ritmo y belleza ${ }^{45}$, y haciéndole posible exclamar:

\footnotetext{
41 San Agustín, De vera religione 52. Citado en: ibid.

42 San Agustín, Enarrationes in Psalmos. 26 12: PL 36, 205-6. Citado en: San Agustín, Escritos filosóficos. $1^{\circ}$. Obras completas. Vol. I. B.A.C.. Madrid 1994, p. 84.

43 San Agustín, Soliloquios 1, 12-13. Citado en: Balthasar, op. cit., n. 36, p. 102.

$44 \quad$ San Agustín, ibid., p. 57.

$45 \quad I d$.
} 
Mirad el mundo cómo resplandece de hermosura. ¡Cuántas maravillas en la tierra, en el mar, en el aire, en el cielo, en las estrellas! [...] Ya no es posible imaginarse espectáculo más bello ${ }^{46}$.

Ante la belleza de la creación, San Agustín llega a decirse a sí mismo: «Mi pregunta era mi mirada; su respuesta era su belleza ${ }^{47}$. Esta misma mirada contemplativa a la que nuestro monje africano invita, secundada por Wackenroder, Friedrich y Novalis, parece ser soslayada por el hombre con la llegada de la Ilustración, para quien la razón ocupando el centro de la vida se aventura como la clave para el progreso. Pero «las lecciones de los sabios sólo ponen en movimiento nuestro cerebro, sólo la mitad de nuestro yo», decía Wackenro$\operatorname{der}^{48}$.

Schiller proponía una solución al respecto en aquellas Cartas para la educación estética del hombre. Siendo consciente de los hechos,

Limitando nuestra actividad a una esfera determinada, nos hemos dado un amo despótico, que a menudo suele acabar por oprimir las restantes potencias del espíritu. Unas veces es el fuego de la imaginación el que consume los tiernos brotes del intelecto; otras veces es el pensar abstracto el que apaga la hoguera donde hubiera podido calentarse el corazón y encenderse la fan$\operatorname{tasía}^{49}$.

Nuestra época es ilustrada; es decir, han sido hallados y públicamente expuestos los conocimientos suficientes para permitirnos rectificar, al menos nuestros principios prácticos. [...] ¿Por qué, pues, permanecemos en la barbarie? ${ }^{50}$.

Schiller busca una respuesta:

Pero esto no basta; en cierto modo no merece respeto [la Ilustración] si no en cuanto que la Ilustración ha de proceder también del carácter, porque el camino que conduce al intelecto ha de abrirlo el corazón. Educar la facultad sensible es, por tanto, la más urgente necesidad de nuestro tiempo, no sólo porque es un medio de hacer eficaces en la vida los progresos del saber, sino porque contribuye a la mejora del conocimiento mismo ${ }^{51}$.

Habrá que buscar para ese fin un instrumento que no nos da el Estado; habrá que alumbrar manantiales de cultura que se mantengan frescos y puros en medio de la mayor podredumbre política.

$\mathrm{Y}$ ahora he llegado ya al punto a que se enderezaban las consideraciones anteriores. Ese instrumento es el arte bello; esas fuentes brotan de los inmortales modelos del arte ${ }^{52}$.

46 San Agustín, Enarrationes in Psalmos. Citado en: ibid., p. 62.

47 San Agustín, op. cit., n. 4, X, 6, 9.

48 WACKENRODER, op. cit., n. 6, pp 156 y 157.

49 Schiller, F., La educación estética del hombre. (García Morente, M., trad.) Col. Austral, Espasa Calpe, Madrid 1968, pp. 27-29.

50 Ibid., pp. 38-39.

${ }^{51} \quad$ Ibid., p. 40.

$52 \quad$ Ibid., p.41. 
La salida planteada es recuperar lo que él denomina la «nobleza del carácter del hombre ${ }^{53}$, siguiendo ese camino abierto por el corazón. Es decir, el hombre no ha de limitarse a conocer, saber, producir y rendir mecánicamente en lo que hace, sino que su otra parte humana, con importancia perfectamente equiparable a la de la razón y el intelecto, a saber, el sentimiento, la emoción, recupere el puesto perdido, para devolver al hombre, con su participación y desarrollo, a su integridad primigenia. Así lo quería también Wackenroder:

¡Pobre época la nuestra!, he de gritar, que sólo practica el arte como un ligero mecanismo de los sentidos, cuando ciertamente es algo muy serio y sublime. ¿Es que ya no se aprecia al hombre, que se le descuida en el arte y que se consideran más dignos que él los colores agradables o cualquier artificiosidad de la luz? ${ }^{54}$.

El Romanticismo reclamaba esta amplia panorámica sobre el mundo, en consonancia con aquellos ojos del corazón y miradas transidas de fe de San Agustín, visto como un lugar de pertenencia para contemplar, más que como un lugar detentado para dominar. Conducidos por esta pretensión, comenzaron a desear crear un objeto a escala de esta visión total, mediante el cual les resultara más sencillo comprender la magnificencia del mundo en todas sus dimensiones, aun siendo conscientes del gran atrevimiento. Es la idea de la obra de arte total, una creación que pudiera ser un reflejo lo más fiel posible a lo que ya San Agustín definía como «la suprema, sublime e inexpresable unidad del Creador ${ }^{55}$. Recordemos cómo los escritores y artistas románticos, incluso los filósofos, impulsados por esa inquietud, hacen desaparecer las fronteras entre las artes. Un pintor escribe poemas, como Friedrich, o tratados sobre arte, como Carl Gustav Carus (1789-1869), que además de pintor era científico; los poetas filosofan, es el caso de Novalis; y un esteta como Wackenroder llegará a escribir versos.

Las obras de estos románticos se convierten en el trasunto de un profundo sentimiento cuyo alcance va más allá de las apariencias, el de la búsqueda y la deseada recuperación de la unidad perdida entre el hombre y el mundo. Un vínculo sondeado en la pura trascendencia, pues ven probado por la historia la dificultad de encontrarlo en la inmanencia de cuanto rodea al hombre y en la finitud de su propio ser. Un lugar que sólo existe en el más intimo meo agustiniano, y que representa «la única esencia eterna, donde no reinan la contradicción, la confusión, el cambio, el defecto, la muerte, sino la concordia suprema, la evidencia suprema la constancia suprema, la plenitud suprema, la vitalidad suprema, en la que nada falta y nada sobra ${ }^{56}$. Destino únicamente alcanzable adoptando aquella disposición de admiración ante lo que rodea al hombre, no

$53 \quad$ Ibid., p. 40.

54 WaCKenRODER, op. cit., n. 6, p. 142.

55 San Agustín, De libero arbitrio 3, 69, Citado en: Balthasar, op. cit., n. 36.

56 San Agustín, Soliloquia 1, 4. Citado en: Balthasar, op. cit., p. 106. 
con deseo de dominio, sustituyendo para ello los experimentos científicos por una suerte de «empirismo del espíritu».

Así, el recorrido del hombre espiritual hacia el sentido de su existencia descrito por San Agustín, se ajusta bien al itinerario personal llevado por los artistas románticos objeto de nuestro estudio. Es un camino que parte de lo exterior, lleva a lo interior, y de ahí, se eleva a lo superior. En Wackenroder hemos apuntado cómo se producía este proceso, pues a medida que profundiza en el conocimiento del arte, se abre para él un mundo nuevo, espiritual y profundo. En el caso de Friedrich, es la soledad la que le lleva de la mano, a través del arte, en este ensimismado itinerario hacia el esclarecimiento de lo que hay en su alma. La muerte de su amada Sophie abre a Novalis la puerta hacia el cielo, ya en la tierra, dentro del refugio de la fe.

Es una situación muy semejante a la que vivirán otros románticos como $\mathrm{F}$. Schlegel, convertido al Catolicismo tras juzgar la belleza de la liturgia católica; o la de Clemens Brentano, amanuense fiel de una pobre religiosa ${ }^{57}$ a la que del cielo llegó el don de la visión mística, que rindió su poesía ante el sobrecogedor relato de lo contemplado por la beata. Recordemos aquí también cómo Joseph von Eichendorff, en aquel segundo Romanticismo de Heidelberg, encontraba en sus poemas el modo de traducir el secreto de su felicidad a pesar de llevar una, aparentemente, sencilla y anodina vida de funcionario, tras la que escondía una gran riqueza mística.

Se trata de una nueva «ciencia», en la que por supuesto la razón, como parte integrante del hombre, igual que su alma y corazón, tiene su lugar, sólo que adquiere tanto para San Agustín, como también para nuestros románticos, una misión de carácter sagrado, la de guiar al hombre hacia su principio y patria: la vida eterna y Dios mismo. Puede hablarse aquí de una «dialéctica de la peregrinación $»^{58}$, no en vano se ha llegado a calificar al obispo africano como "peregrino de lo absoluto»" ${ }^{59}$ Y qué son si no nuestros autores, cuyas vidas, sintetizadas en las líneas precedentes, constituyen un reflejo de ese peregrinar al que, en definitiva, nos venimos refiriendo a lo largo de este artículo. Pensemos por un momento en la insistente presencia de peregrinos y caminantes en toda la obra de Friedrich. Su figura podría ser considerada como el leitmotiv de su producción artística, corporeizando, como el monje, el estado de su alma, siempre en camino, siempre buscando, en profundo recogimiento tendido hacia la infinitud e inmortalidad. Pareja inquietud dirige los pasos del mismo Enrique de Ofterdingen, personaje que Novalis creó también con el molde de peregrino, en camino hacia aquella misteriosa flor azul ${ }^{60}$.

57 Anna Catalina Emmerich, además monja agustina.

58 Balthasar, op. cit., n. 36, p. 71.

59 Ibid., p. 79.

60 En los encuentros que Enrique vive con los distintos personajes en su camino a casa de su abuelo, se distingue una concepción de la naturaleza y la vida del poeta que manifiestan la tensión hacia lo divino y trascendente de la que venimos hablando. En consonancia, a lo largo de la narración la imagen de la flor azul va adquiriendo la dimensión de corporeizar los 
Explica von Balthasar, precisamente, que a San Agustín «lo que le interesa es la actitud dinámica del alma hacia Dios, no la construcción de argumentos y teorías. Trata de mostrar que la creación no puede dar al hombre la completa felicidad que busca, sino que apunta por encima de ella al Dios viviente que hay que buscar dentro de uno mismo» ${ }^{61}$. Entonces el mundo puede ser asimilado, además de para ser contemplado, como una invitación a participar en el ser absoluto, y por ello también como un lugar de paso. La aceptación de esta invitación es lo revelado con su vida y obra por estos artistas y escritores. A esto lo llama el teólogo alemán la «mirada estético-religiosa a la visión de Dios», o lo que es lo mismo: «las cosas revelando a Dios, remiten más allá de sí a Dios, ocultan en sí a Dios para revelar a Dios en Dios» ${ }^{62}$.

Es esta conciencia, esta experiencia la que lleva a San Agustín a exclamar:

Si te agradan los cuerpos, alaba a Dios por ellos. Haz que revierta tu amor sobre el Artífice que los plasmó. [...] Si te agradan las almas, ámalas en Dios, [...] y arrastra hacia Dios a todas las almas que puedas. [...] Él está donde se saborea la verdad. Está en lo más íntimo del corazón, pero el corazón se ha ausentado de Él.

Prevaricadores, volved al corazón y adheríos a Aquél que os ha creado. Manteneos en su compañía y alcanzaréis estabilidad. Descansad en Él y hallaréis sosiego. ¿A dónde vais? El bien que amáis procede de Él [...] ¿Qué interés tenéis en seguir sendereando por trochas y vericuetos trabajosos? [...] Estáis buscando la vida feliz en la región de la muerte.

Él es el objeto de la confesión de mi alma. [...] Y vosotros, hijos de los hombres, ¿hasta cuándo vais a ser pesado de corazón? ¿A dónde subís, si ya estáis en las alturas y habéis puesto vuestra boca en el mismísimo cielo? Bajad para que podáis subir hasta Dios $^{63}$.

Palabras que encuentran de nuevo la replica en el eco agustiniano de Wackenroder:

$\mathrm{El}$ arte, flor del sentimiento humano, eleva desde la tierra hacia el cielo, y esa semilla exhala el único aroma hacia el padre común. [...] Y cuando, a través del inconmensurable espacio del cielo retorno desde Él, el infinito, a la tierra y busco entre mis hermanos, jah!, entonces he de lamentarme en alta voz de que apenas aspiren a parecerse a su eterno gran ejemplo del cielo. [...] Creen que el sitio en el que están es el centro de gravedad del mundo y su espíritu carece de alas para sobrevolar todo el globo. [...] $]^{64}$.

Cabezas críticas que ni quieren, ni pueden creer en todos los espíritus extraordinarios, así como en todas las maravillas sobrenaturales y quisieran reducir el mundo a prosa ${ }^{65}$.

anhelos humanos reconocidos en el corazón del hombre por Novalis. Anhelos manifiestos en sus poemas, así como también en el relato de Los discípulos de Sais.

61 Balthasar, op. cit., p. 110.

62 Id.

63 SAn Agustín, op. cit., n. 4, IV, 13, 18-19.

${ }_{64}$ WaCKenRoder, op. cit., n. 11, pp. 120-131.

${ }_{65}$ Ibid., p. 89. 
Los filósofos han querido desvelar los secretos del cielo y ponerlos bajo los asuntos terrenales, y expulsar de su pecho los sentimientos oscuros. [...] El arte abre los tesoros en nuestro corazón, dirige la mirada a nuestro interior [...] se asemeja a oráculos incompletos de boca de la divinidad ${ }^{66}$.

¿Y que no reconozcan en ello, como en el resto de la naturaleza, la huella del dedo de Dios? ${ }^{67}$.

El amor nos abre los ojos sobre nosotros mismos y sobre el mundo, el alma se vuelve más tranquila, más devota, y de todos los rincones del corazón prorrumpen miles de sentimientos ardientes en llamas luminosas: es cuando uno aprende a entender la religión y los milagros del cielo, el espíritu se vuelve más humilde ${ }^{68}$.

Se trata de una mirada dirigida al horizonte infinito, semejante a la de aquel Monje, inmortalizado para nosotros en el cuadro de Friedrich. Una visión que, a pesar de las deficiencias de su finitud, pretende, o encierra al menos, el deseo de alcanzar siquiera un anticipo de aquello que tiene ante sí, de momento incognoscible, pero ardientemente anhelado. Se trata de su destino y del sentido de su vida: la eternidad, y ésta contenida, no en un espacio etéreo e ideal, sino real y vivo, como es el seno de un Dios personal que le ama. Es el retrato del hombre ante el misterio del mundo, y en nuestro caso ante el misterio divino, al que dan vida los autores románticos a los que nos venimos refiriendo.

Decíamos que a orillas del mar San Agustín meditaba sobre el Misterio de la Santísima Trinidad, y tres son las franjas de color y elementos ante las cuales cavila, con la mano colocada en la barbilla, el monje de Berlín. Tres fueron además los objetos de las inquietudes contenidas en el corazón de aquel pintor alemán de Dresde, cuyas costumbres tan similares eran a las de un monje según los testimonios de quienes le conocieron ${ }^{69}$. Los temas de sus cuadros coinciden con los de sus textos ${ }^{70}$, el hombre, el mundo y Dios, y la relación entre ellos constituyen la personal «trinidad» de Friedrich.

No sabía nuestro primer monje que ante el mar se cuestionaba y preguntaba sobre el mundo, Dios, sus tres personas y razones, que encontraría sus resonancias también, además de sobre los papeles de Wackenroder, en la imagen de Friedrich, pues hay cuestiones en la vida del hombre que, como las olas, van

${ }_{66} \quad$ Ibid., pp. 158-159.

67 Ibid., p. 89.

68 Ibid., p. 103.

${ }^{69}$ Así lo detalla el naturalista G. H. von Schubert y C. G. Carus (Börsch-Supan, H., JäHRING, K. S., Caspar David Friedrich. Gemälde, Drückgraphik und Bildmässige Zeichnungen. Prestel, Múnich 1973, p. 218 y p. 239); así como el también amigo de Friedrich, Wilhelm von Kügelgen (NaKama, Y., Caspar David Friedrich und die Romantische Tradition. Dietrich Reimer Verlag, Berlín 2011, p. 34).

70 Los textos legados por Friedrich se encuentran recopilados en FrIEdRICH, C. D., Bekenntnisse. Eberlein, K. (ed.), Europäischer Hohschul Verlag, Bremen 2010. Tanto en sus reflexiones teóricas sobre arte, como en sus poemas, se pone al descubierto una intensa vida interior alimentada por la fe religiosa vivida con profunda convicción. 
y vienen en un movimiento incesante. Cuando al pintor le preguntaron sobre el significado de esta obra, muy claramente lo dejaba por escrito en una carta:

Comparto con usted una descripción de uno de los cuadros que he terminado recientemente. Realmente son más bien mis pensamientos sobre la obra, así que quizá no pueda estrictamente llamarse descripción. Es un paisaje marítimo, con una desierta playa de arena en primer plano, después, el mar, con oleaje, y finalmente el aire. En la playa hay un hombre, pensando profundamente, con una túnica negra; las gaviotas graznan a su alrededor, como si quisieran advertirle que no se atreva a acercarse al mar impetuoso.

Esta es la descripción, ahora vienen mis pensamientos al respecto. Podrías pensar, reflexionar desde la mañana a la tarde, desde la tarde hasta la media noche, y a pesar de todo jamás llegarías a imaginar, a averiguar, nada sobre el insondable más allá. Con traviesa arrogancia, ¿osas a convertir el mundo de la noche en luz? ¿A despejar la incógnita del futuro incierto? Eso es algo exclusivamente sagrado, que únicamente puede verse y conocerse, saberse y entenderse de forma clara finalmente por medio de la fe $\mathrm{f}^{71}$.

Así, la creación se convierte en una gran pintura en la que hay luces, pero también sombras ${ }^{72}$. Y ¿qué es la mística sino la unión entre lo que se oculta y quien busca revelarlo, entre el ser del misterio y el ser que, desprovisto de él, padece su necesidad? El alma predispuesta a entablar esta temeraria relación, posee la «cualidad estética de percibir en la verdad la cualidad de lo eterno, de lo divino, para lo que es necesario el recogimiento y la purificación $»^{73}$, y únicamente quien goza con esta visión descubre la dimensión estética de la vida, es decir, «sólo quien gusta la revelación del infinito en la forma finita es no sólo místico, sino esteta» ${ }^{74}$.

Nos encontramos ante una estética especial no elaborada para los sentidos del cuerpo, sino para el alma. Por medio de esta experiencia, el hombre comienza a recorrer un camino hacia lo que se le oculta tras las formas visibles, un camino marcado por Aquél que reunió en sí mismo lo oculto y lo visible, en sus dos naturalezas, humana y divina. El mundo es visto por nuestros autores como una nueva "epifanía», con la pretensión de reconstituirlo como reverberación de aquella primera realizada en el mismo Cristo, homenajeado en tantas pinturas de Friedrich mediante aquellas altas y sublimes cruces, así como en numerosos poemas de Novalis. Conciliador y mediador entre el hombre y Dios, se convierte por su kénosis en «revelación de la belleza y plenitud de Dios»,

${ }^{71}$ Texto escrito por el pintor encontrado entre los papeles de Amelie von Bibra (17681826), esposa del cuñado de Schiller, Friedrich Wilhelm Ludwig von Beulwitz (1765-1829). Börsch-Supan, H., «Berlin 1810. Bildende Kunst. Aufbruch unter dem Druck der Zeit», en: Kleistjahrbuch. 1987. Erich Schmidt Verlag. Berlín 1987, p. 74. Texto datado entre otoño de 1809 y verano de 1810 .

${ }_{72}$ O'Connell, R. J., (SJ) Art and the Christian intelligence in St. Augustine. Harvard University Press, Cambridge, Massachusetts 1978, p. 157.

73 Ibid., p. 113.

74 Ibid., p. 116. 
según San Agustín, quien afirma al mismo tiempo que así es posible decir sobre este itinerario interior y espiritual que «el camino mismo es belleza ${ }^{75}$.

$\mathrm{Al}$ adquirirse conciencia de la magnitud de lo bello desde la perspectiva de alguien que cree encontrarse ante un ser, y no sólo frente a un fenómeno, es decir, al producirse una «tensión dinámica hacia una unidad espiritual y divina ${ }^{76}$, la experiencia estética alcanza así la dimensión de experiencia religiosa. Ésta última es siempre estética, sin embargo, la novedad que introducen los románticos en su época es retomar para sus contemporáneos el recorrido contrario, pues a la inversa no sucede, es decir, la experiencia estética ni mucho menos es en toda ocasión religiosa, y en su tiempo lo que prevalecía era este tipo de vivencia aséptica, desvinculada de lo espiritual, anclada en el puro gusto, vacunada contra la virulencia de un espíritu encendido, no por un fuego cualquiera, sino por el que habla de un Dios que se hace presente en lo que se contempla. Es la zarza ardiente en clave moderna.

Esta actitud, predisposición y reacción ante la belleza de la creación, tan antigua como San Agustín y atesorada por Meister Eckhart, y por los autores sucesivos que hemos mencionado, es lo que rescatan del pasado nuestros románticos. No solamente se trata entonces de representar ruinas, destellos de mundos medievales, o lejanos, sin más. Habría que traducir estos tres elementos —ruinas, medievo, exotismo-, tan caros a la estética romántica, respectivamente, por la necesidad de reconstruir para el siglo lo que dentro del hombre se encuentra abandonado, ruinoso y descuidado, que es su alma con la condición de inmortalidad; por la referencia a una época donde la fe era lo más natural y cotidiano de la vida de los hombres, como hacía Novalis en su Cristiandad o Europa; y por los testimonios que evidencian cómo la mano del Creador se manifiesta también en la gran diversidad y belleza de la propia creación, a la vista de tantas formas como lugares, de preciosa variedad y riqueza, muestras de la generosidad de una mano que ha procurado al hombre un mundo lleno de color, de hombres de toda raza y condición, y de paisajes de mil naturalezas.

Una conciencia sobre el mundo que Adolf Harnack denomina «optimismo estético ${ }^{77}$, y lo hace refiriéndose a San Agustín, explicando que se trataba de «la contemplación de la totalidad del mundo desde una visión en que la mirada abarca "todo el diseño del mosaico del pavimento" y no sólo una pieza suelta. Es el mundo visto a la luz de Dios» ${ }^{78}$. Esta "agustiniana concepción artística de lo real» ${ }^{79}$, reflejada en su «lirismo inagotable para cantar las bellezas de lo creado ${ }^{80}$ es recuperada por nuestros románticos alemanes para el mundo de su época, sólo que ya no se trata de ese «optimismo» en sí mismo, sino de la

75 San Agustín, De libero arbitrio. 2, 45, y Enarrationes in Psalmos, 123, 2. Citado en: Balthasar, op. cit, n. 36, p. 124.

76 Ibid., p. 130.

77 HaRnack, A., Lehrbuch der Dogmengeschichte. Citado en: op. cit., n. 36, p. 128.

78 Id.

79 San Agustín, op. cit., n. 42, p. 83.

$80 \quad$ Id. 
melancolía experimentada por el deseo de recuperarlo, responsable de la recreación en las obras de nuestros autores de todos aquellos elementos a los que nos referíamos, y que las constituyen en reclamo escondido tras la belleza del arte y de la poesía, hacia un "renacimiento» de ese optimismo.

$\mathrm{El}$ arte, la literatura y la música no son para ellos fines en sí mismos, o meros canales de deleite para el lector, espectador u oyente, sino que son caminos convergentes en una sola vía, la via pulchirtudinis, la vía de la belleza para alcanzar a Dios.

$\mathrm{El}$ arte es instrumentalizado por Wackenroder en esta dirección, quien afirmaba comparar "el disfrute de las más nobles obras de arte con la oración», reconociendo en ellas un medio no únicamente para despertar un gozo sensible, sino dignas de ser utilizadas «respetuosamente para la salvación del alma», pues «van más allá de lo regular y cotidiano, y debemos elevarnos hacia ellas con todo nuestro corazón para, en esos ojos nuestros tan a menudo turbios por la niebla de la atmósfera, hacer de ellas lo que son, conforme a su sublime esencia ${ }^{81}$.

Es el salto que ha de dar el Monje salido de la paleta y del corazón de Friedrich, si quiere saber qué le aguarda en la otra orilla, el de reconocer en la belleza de lo visible un trasunto de lo invisible; es la noche de los Himnos que el corazón pasa al borde de la muerte en Novalis, por ella cegado durante un instante antes de, acto seguido, contemplar la verdadera luz para el alma. Luz que ya no es Aufklärung (entendida como esclarecimiento) para la vida en el mundo, sino Erleuchtung (iluminación) para toda la eternidad.

Esta «trindad romántica», Wackenroder, Friedrich, Novalis, busca descubrir para sus contemporáneos una entrada a este universo, inmortal, auténtico festín para el alma, ofreciéndoles una de las llaves que la abren, la de la belleza. La obra de nuestros románticos puede ser vista entonces como la puesta en imágenes, poéticas y plásticas, de aquel sentimiento agustiniano, «nos hiciste Señor para ti, y nuestro corazón estará inquieto hasta que descanse en ti», y del deseo profundo de tal corazón:

Yo quiero el ser perfecto; yo quiero el ser verdadero; yo quiero el ser puro; yo quiero aquel ser que está en la Jerusalén celeste, esposa de mi Señor; allí no habrá muerte, ni mudanza, ni días transitorios, sino una perpetua eternidad, que no es devorada ni empujada por la sucesión de los tiempos ${ }^{82}$.

El monje Agustín, hermano confeso del monje de Wackenroder, que ha saltado de aquellas páginas hasta la orilla de una playa con Friedrich y se convierte en templo del corazón ardiente de Novalis, se transforma en la figura del poeta, del artista, en el semblante de su alma, en una especie de celebrante del misterio de la existencia, que dispone al hombre, transfigurado en partícipe de esta sublime ceremonia, ante el altar de la vida y el presbiterio del mundo.

81 WACKENRODER, op. cit., n. 6, pp. 172-173.

82 San Agustín, Enarrationes in Psalmos. 38 7: PL 36, 419. Citado en: San Agustín, op. cit., n. 42, p. 292. 
Se ha erigido un nuevo templo en el alma humana, y el artista, el poeta, se convierte en una suerte de consagrado a la orden de la belleza, que custodia el culto vivido en la espiritualidad olvidada por el hombre filósofo e ilustrado y oficia para el hombre de su tiempo la nueva liturgia de la sensibilidad, del sentimiento, del espíritu, de una trascendencia que ya no se llama idea, sino Dios, Creador, sobre quien el poeta es capaz de cantar:

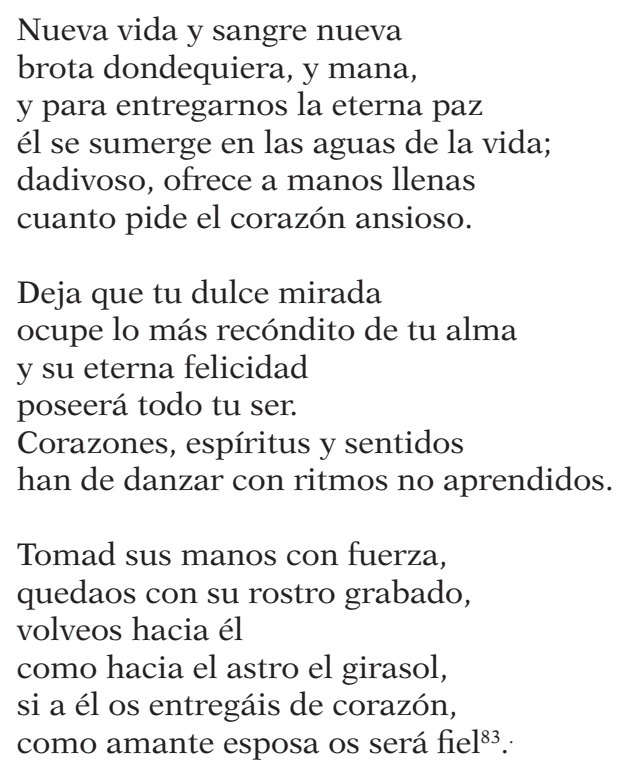

Tomad sus manos con fuerza, quedaos con su rostro grabado, volveos hacia él como hacia el astro el girasol, si a él os entregáis de corazón, como amante esposa os será fiele ${ }^{83}$.

Universidad Pontificia Comillas, Madrid

mgvazquez@comillas.edu

Milagros García Vázouez

[Artículo aprobado para publicación en enero de 2019]

83 Novalis, Poesías completas. Los discípulos de Sais. DVD Poesía, Barcelona 2004, p. 53 